\title{
KEADILAN ORGANISASIONAL, TRUST, DAN KOMITMEN ORGANISASIONAL BERPENGARUH TERHADAP ORGANIZATIONAL CITIZENSHIP BEHAVIOR PADA KARYAWAN
}

\author{
Ida Ayu Phrameswari Dwika ${ }^{1}$ \\ I Gusti Ayu Dewi Adnyani ${ }^{2}$ \\ ${ }^{1,2}$ Fakultas Ekonomi dan Bisnis Universitas Udayana (Unud), Bali, Indonesia \\ email: phrameswari.dwika@yahoo.com
}

\begin{abstract}
ABSTRAK
Organizational citizenship behavior merupakan perilaku individu yang bersifat sukarela diluar deskripsi pekerjaannya yang tidak diatur dalam perusahaan dan dapat meningkatkan efektifitas dan efisiensi fungsi perusahaan. Agar tumbuh perilaku OCB pada karyawan Impiana Private Villas Seminyak perusahaan perlu memperhatikan beberapa faktor yang mempengaruhi OCB seperti keadilan organisasional, trust, dan komitmen organisasional. Tujuan dari penelitian ini adalah untuk menjelaskan pengaruh keadilan organisasional, trust, dan komitmen organisasional terhadap OCB. Penelitian ini dilakukan pada Impiana Private Villas Seminyak. Sampel dalam penelitian sebanyak 106 responden dengan metode simple random sampling dan dihitung dengan rumus slovin. Teknik Analisis yang digunakan adalah regresi linier berganda. Keadilan organisasional berpengaruh positif dan signifikas terhadap OCB, trust berpengaruh positif dan signifikas terhadap OCB, dan komitmen organisasional berpengaruh positif dan signifikas terhadap OCB. Hasil uji kelayakan model didapat bahwa keadilan organisasional, trust, dan komitmen organisasional berpengaruh signifikan secara serempak atau bersama-sama terhadap organizational citizenship behavior karyawan Impiana Private Villas Seminyak.

Kata kunci: organizational citizenship behavior, keadilan organisasional, trust, dan komitmen organisasional.
\end{abstract}

\begin{abstract}
Organizational citizenship behavior is a behavior to work voluntary outside the job description and can increase the effectiveness and efficiency of company functions. In order to grow OCB in Impiana Private Villas Seminyak employees, the company needs to pay attention to organizational justice, trust, and organizational commitment. Purpose of this study is to explain the effect of organizational justice, trust, and organizational commitment on OCB. Sample are 106 respondents with the simple random sampling method and calculated using the Slovin formula. The analysis technique used is multiple linear regression. Organizational justice has a positive and significant effect on $O C B$, trust has a positive and significant effect on $O C B$, and organizational commitment has a positive and significant effect on $O C B$. The results of the model feasibility test found that organizational justice, trust, and organizational commitment significantly influence simultaneously or together on organizational citizenship behavior of Impiana Private Villas Seminyak employees.

Keywords: organizational citizenship behavior, organizational justice, trust, and organizational commitment.
\end{abstract}




\section{PENDAHULUAN}

Sebuah organisasi perlu membenahi diri untuk menuju organisasi yang lebih efektif agar sumber daya manusia bisa bekerja lebih baik lagi, namun pada kenyataannya tidak semua orang mampu bekerja sebagai anggota tim. Teori yang menaungi hubungan antara keadilan organisasional, trust dan komitmen organisasional dengan organizational citizenship behavior yaitu teori pertukaran sosial (Social Exchange Theory). (Candika \& Chairoel, 2018). Dalam teori pertukaran sosial dikatakan bahwa karyawan yang merasa diperlakukan adil oleh organisasi, memiliki kepercayaan (trust) terhadap organisasinya dan juga memiliki komitmen yang tinggi, maka akan memunculkan perilaku extra-role atau yang dikenal dengan organizational citizenship behavior terhadap suatu organisasi dalam perusahaan (Lakshmi \& Simarmata, 2015).

Organizational citizenship behavior merupakan perilaku individu yang mencerminkan peran dalam organisasi, yang bukan merupakan peran utamanya, peran ini diambil tanpa adanya harapan apapun yang kemudian dapat membawa organisasi kearah efisiensi dalam bidang operasional dan organisasional. OCB dalam perusahaan dapat membantu meningkatkan kinerja tugas atau kinerja organisasional. Organizational Citizenship Behavior (OCB) merupakan perilaku sukarela dari seorang pekerja untuk melakukan tugas atau pekerjaan di luar tanggung jawab atau kewajibannya (Putra \& Sriathi, 2017).

Observasi awal yang dilakukan pada karyawan Impiana Private Villas Seminyak mendapatkan hasil bahwa tingkat OCB karyawan cukup rendah. Rendahnya tingkat OCB ini ditunjukkan dari sikap karyawan yang kurang peduli terhadap rekan kerja yang membutuhkan pertolongan. Karyawan hanya mengerjakan tugas-tugas yang merupakan tanggung jawabnya sendiri, kurang memiliki inisiatif untuk menolong dan mereka baru bereaksi ketika ditegur atau diperintahkan oleh atasan ataupun senior mereka. Sikap seperti ini kurang mendukung efektivitas dalam Impiana Private Villas Seminyak karena banyak waktu yang terbuang dengan tidak produktif.

Terdapat beberapa faktor dalam suatu organisasi yang menimbulkan organizational citizenship behavior. Diantaranya adalah keadilan, kepercayaan dan memiliki komitmen yang tinggi di dalam organisasi. Para karyawan mengharapkan diperlakukan sama dan adil oleh manajemen (Mada et al., 2017).. Hal ini akan mengarah pada kepercayaan di antara karyawan dan ketika mereka memiliki kepercayaan, secara tidak langsung karyawan akan memiliki komitmen yang tinggi terhadap organisasinya. Mereka akan bekerja keras untuk mencapai tujuan organisasi, dimana pekerjaan itu bukanlah pekerjaan utamanya yang dilakukan secrara sukarela (Leelamanothum et al., 2018)

Keadilan organisasi mengacu pada persepsi pengembalian yang diterima dari organisasi dengan proses pertimbangan yang tepat dan memperlakukan orangorang secara adil. Keadilan organisasi dapat dilihat dari pengambilan keputusan yang dilakukan pimpinan perusahaan, dimana karyawan diikutsertakan dalam proses pengambilan keputusan. Organisasi menjadi alat pendorong untuk karyawan terus mempertahankan kemampuan serta keunggulan kompetitif (Tlaiss \& Elamin, 2015). Menurut Kristanto (2015), penting diketahui bahwa baik karyawan maupun organisasi berhak dipercaya untuk memenuhi tanggung jawab yang harus 
dibayarkan dalam pertukaran sosial. Alokasi sumber daya, proses pengambilan keputusan, dan prosedur organisasi harus dilakukan dengan adil sesuai dengan persepsi karyawan. sikap pekerja dipengaruhi oleh perlakuan yang adil oleh organisasi.

Permasalahan yang berkaitan dengan keadilan organisasional yaitu sikap tidak adil perusahaan kepada karyawan. Berdasarkan hasil wawancara dengan karyawan Impiana Private Villas Seminyak dikatakan bahwa karyawan merasa keputusan yang diterapkan oleh perusahaan tidak konsisten kepada semua karyawan. Yaitu pada masalah jam kerja yang diberikan. Karyawan yang telah lebih lama bekerja dapat menukar jam kerja dengan mudah dibanding dengan masa kerja nya yang masih baru. Hasil wawancara ini menunjukkan terdapat gejala kurangnya keadilan organisasi yang dirasakan karyawan di Impiana Private Villas Seminyak.

Kepercayaan (trust) adalah suatu eskpektasi dan pengharapan positif bahwa orang lain tidak akan melalui kata-kata, tindakandan kebijakan bertindak secara oportunistik. Kepercayaan pada organisasi adalah apa yang orang andalkan, mengarah pada kerjasama dalam penggunaan sumber daya untuk efisiensi maksimum. Kepercayaan terkait dengan perilaku personel dalam hubungan organisasi (Fard \& Karimi, 2015). Kepercayaan dalam manajemen, jaminan tentang tindakan mereka, kejujuran dan harapan positif membentuk beberapa komponen yang menjadi dasar kepercayaan bagi karyawan. Ini merupakan hasil dari proses pertukaran sosial di mana karyawan menafsirkan dan membalas tindakan dan terusmenerus memantau lingkungan kerja untuk menilai apakah mereka harus mempercayai manajemen puncak. Organisasi dengan tingkat kepercayaan yang tinggi lebih sukses, karena perilaku pekerja nya menunjukkan sikap sebagai makhluk sosial dan mau membantu pekerjaan lainnya di luar pekerjaan utamanya (Firaz, 2015).

Fenomena masalah mengenai trust (kepercayaan) pada Impiana Private Villas Seminyak dapat dilihat dari sikap karyawan yang tidak mempercayai perusahaan tempat mereka bekerja. Jika terjadi masalah pada pekerjaan, karyawan lebih memilih membicarakannya kepada rekan kerja nya dibanding kepada manajer. Menunjukkan bahwa karyawan bersifat tidak terbuka dengan perushaaan, dan juga ada hal yang disembunyikan karyawan dari perusahaan. Hal ini terjadi karena karyawan merasa tidak dapat mempercayai perusahaan. Dapat dikatakan bahwa kepercayaan karyawan di Impiana Private Villas Seminyak masih terbilang rendah.

Faktor yang dapat mendorong munculnya OCB adalah komitmen terhadap organisasi yang dimana terdapat kemauan yang kuat untuk berpartisipasi lebih dengan baik di dalam organisasi serta merasa bangga menjadi satu bagian dari organisasi. Pentingnya membangun OCB dalam lingkungan kerja, tidak lepas dari bagaimana komitmen yang ada dalam diri karyawan tersebut. Komitmen organisasional menjadi salah satu faktor penting yang berpengaruh dalam terciptanya OCB dalam organisasi. Komitmen merupakan faktor pendorong yang kuat untuk mempertahankan keanggotaan dalam organisasi demi tercapainya tujuan organisasi (Gunastri et al., 2019)

Komitmen organisasi adalah suatu keadaan dimana seorang karyawan memihak pada suatu organisasi tertentu dan tujuan-tujuannya dan keinginannya untuk mempertahankan keanggotaan dalam organisasi tersebut (Udayana, 2015). 
Komitmen organisasi dapat menghasilkan tenaga kerja yang stabil dan produktif. Karyawan yang berkomitmen biasanya berorientasi inovatif dan memiliki tujuan akhir untuk meningkatkan kinerja. Efek positif dari komitmen organisasi, yang meliputi perasaan puas, keterikatan terhadap organizational citizenship behavior yang ditujukan untuk meningkatkan efisiensi dan efektivitas organisasi (Siregar et al., 2015).

Tingkat perputaran karyawan pada Impiana Private Villas Seminyak yaitu masih terdapat karyawan yang keluar dan masuk karena merasakan tidak puas didalam melakukan pekerjaan. Berdasarkan hasil wawancara dengan HRD Impiana Private Villas Seminyak, bahwa dalam kurun waktu satu tahun terdapat pegawai yang keluar masuk perusahaan (turn over). Hal ini mengindikasikan komitmen organisasi dari karyawan Impiana Private Villas Seminyak mengalami permasalahan, berarti komitmen organisasi di Impiana Private Villas Seminyak perlu ditingkatkan. Penilitian ini dilakukan di Impiana Private Villas Seminyak yang bergerak di bidang pariwisata dan berlokasi di Jl. Kunti I No. 118x, Seminyak, Bali. Impiana Private Villas Seminyak dalam menjalankan bisnis nya diperlukan karyawan yang mampu melakukan pekerjaan secara maksimal, dan memiliki rasa kekeluargaan terhadap karyawan lainnya. Impiana dipilih sebagai lokasi penelitian karena terdapat dugaan bahwa OCB pada karyawan Impiana Private Villas Seminyak tergolong cukup rendah. Tujuan penelitian adalah Untuk mengetahui pengaruh keadilan organisasional terhadap organizational citizenship behavior pada Impiana Private Villas Seminyak, Untuk mengetahui pengaruh trust terhadap organizational citizenship behavior pada Impiana Private Villas Seminyak dan Untuk mengetahui pengaruh komitmen organisasional terhadap organizational citizenship behavior pada Impiana Private Villas Seminyak.

Nandan \& Abdul (2015) dan Nwibere (2015) menemukan bahwa keadilan organisasional dan dimensi dari keadilan organisasional memiliki hubungan positif dan signifikan dengan organizational citizenship behaviour (OCB). Ketika karyawan merasa telah diperlakukan secara adil oleh perusahaan maka perilaku extra-role dari karyawan meningkat. Ibrahim \& Ann (2015) dalam penelitiannya juga menunjukkan bahwa keadilan organisasional berpengaruh postitif dan signifikan terhadap organizational citizenship behavior. Semakin tinggi keadilan yang dirasakan oleh karyawan maka perilaku extra-role (OCB) juga akan terjadi, hal ini dikemukakan dalam penelitian Mustafa et al. (2016). Penelitian lain yang dilakukan Demirel et al. (2018) mengungkapkan hubungan positif dan signifikan antara keadilan organisasional dan organizational citizenship behavior. Mengarah pada uraian tersebut, hipotesis yang dapat dikembangkan dalam penelitian ini adalah sebagai berikut.

$\mathrm{H}_{1}$ : Keadilan organisasional berpengaruh positif dan signifikan terhadap organizational citizenship behavior

Penelitian yang dilakukan oleh Makhdoom et al. (2016) pernyataan juga didukung bahwa kepercayaan memiliki pengaruh yang positif terhadap OCB. Suyono \& Sunaryo (2015) menyelidiki hubungan antara tingkat kepercayaan organisasi perawat dan OCB mereka. Hasil penelitian menunjukkan bahwa perawat yang mempercayai manajer, organisasi, dan rekan kerja mereka menunjukkan perilaku extra-role atau yang dikenal dengan OCB. Singh \& Srivastava (2016) 
melakukan penelitian tentang pengaruh peningkatan kepercayaan organisasi terhadap OCB. Hasil dari penelitian ini yaitu meningkatkan kepercayaan organisasi memiliki efek positif terhadap OCB. Pourkeiani et al. (2016) mengemukakan bahwa trust berpengaruh secara signifikan dan positif terhadap organizational citizenship behavior. Begitu juga dengan Leelamanothum et al. (2018) yang meneliti pengaruh justice, trust terhadap organizational citizenship behavior, dimana trust berpengaruh positif terhadap organizational citizenship behavior. Mengarah pada uraian tersebut, hipotesis yang dapat dikembangkan dalam penelitian ini adalah sebagai berikut.

$\mathrm{H}_{2}$ : Trust berpengaruh positif dan signifikan terhadap organizational citizenship behavior

Günay (2018) dalam penelitiannya menyatakan bahwa ada hubungan yang signifikan antara komitmen organisasional dan OCB dikalangan perempuan pekerja di sektor tekstil. Hasil penelitian Diatmika \& Suwandana (2016) menunjukkan bahwa komitmen organisasional berpengaruh positif dan signifikan terhadap organizational citizenship behavior di Alam Puri Villa Art Museum Resort and Spa Penatih Denpasar. Kurniawan (2015) menguji hubungan antara komitmen organisasi dan OCB, disimpulkan oleh mereka bahwa komitmen organisasional secara positif dan signifikan terkait dengan OCB. Selaras dengan temuan dari Asiedu et al. (2015) dikatakan bahwa karyawan yang memiliki komitmen tinggi cenderung akan melakukan pekerjaan dengan efektif termasuk juga beperilaku OCB. Begitu pula dengan penelitian yang dilakukan oleh Ferdus \& Kabir (2018) bahwa komitmen organisasional berpengaruh secara positif dan signifikan dengan organizational citizenship behavior. Mengarah pada uraian tersebut, hipotesis yang dapat dikembangkan dalam penelitian ini adalah sebagai berikut.

$\mathrm{H}_{3} \quad$ : Komitmen Organisasional berpengaruh positif dan signifikan terhadap organizational citizenship behavior.

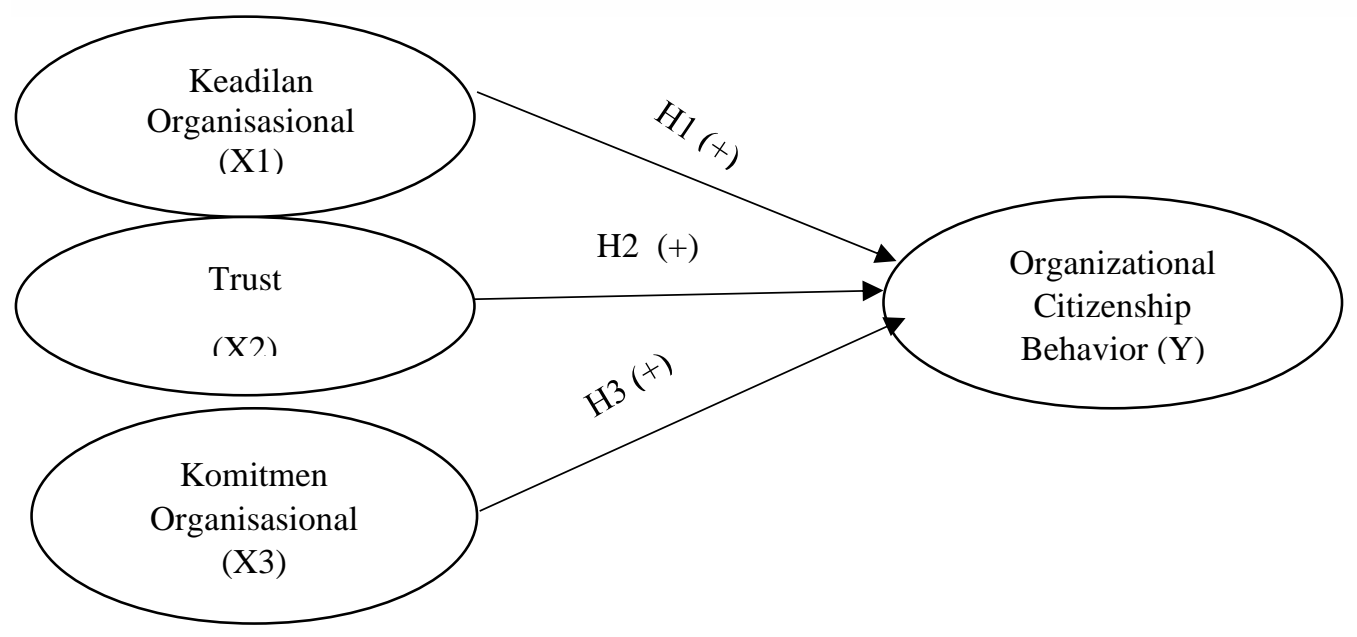

Gambar 1. Kerangka Konseptual Penelitian 


\section{METODE PENELITIAN}

Desain penelitian yang digunakan dalam penelitian ini bersifat asosiatif. Lokasi penelitian ini dilakukan di Impiana Private Villas Seminyak yang beralamat di Jl. Kunti I No. 118x, Seminyak, Bali. Lokasi ini dipilih karena ditemukan masalah-masalah yang terkait dengan organizational citizenship behavior. Objek penelitian dalam tulisan ini adalah keadilan organisasional, trust, komitmen organisasional dan organizational citizenship behavior di Impiana Private Villas Seminyak. Variabel terikat dalam penelitian ini adalah organizational citizenship behavior. Variabel bebas dalam penelitian ini adalah keadilan organisasional, trust dan komitmen organisasional.

OCB dalam penelitian ini merupakan segala perilaku karyawan dengan tulus dan sukarela dalam melakukan pekerjaan yang melebihi tuntutan formalnya untuk mendukung keefektifan perusahaan. Indikatornya yaitu 1) Altruism, merupakan tindakan suka rela yang dilakukan oleh karyawan untuk menolong rekan kerja tanpa mengharapkan imbalan apapun. Indikator ini diukur melalui persepsi responden terhadap tindakan suka rela yang dilakukan untuk menolong rekan kerja tanpa mengharapkan imbalan, 2) Conscientiousness, adalah kesungguhan karyawan dalam bekerja, dimana karyawan bekerja melebihi deskripsi kerja yang telah ditetapkan dan diharapkan perusahaan. Indikator ini diukur melalui persepsi responden tentang melakukan pekerjaan melebihi deskripsi yang telah ditetapkan perusahaan. 3) Courtesy, merupakan sikap menjaga hubungan baik dengan rekan kerjanya agar terhindar dari masalah - masalah interpersonal. Indikator ini diukur melalui persepsi responden tentang menjaga baik hubungan dengan rekan kerja untuk menghindari masalah interpersonal 4) Sportsmanship, yaitu perilaku karyawan yang memiliki toleransi tinggi dan mampu beradaptasi dengan situasi lingkungan kerjanya. Indikator ini diukur melalui persepsi responden mengenai kemampuan beradaptasi dengan lingkungan kerja. 5) Civic virtue, merupakan perilaku individu yang bertanggung jawab pada perusahaan untuk ikut berpartisipasi secara penuh dalam kegiatan-kegiatan dalam perusahaan. Indikator ini diukur melalui persepsi responden untuk ikut berpartisipasi secara penuh dalam kegiatan-kegiatan yang diselenggarakan perusahaan.

Keadilan organisasional dalam penelitian ini merupakan persepsi seorang karyawan yang dirasakan terkait organisasi yang mampu memberikan perlakuan yang adil kepada karyawan (Suardani \& Supartha, 2018). Indikator variabel keadilan organisasional dalam penelitian ini: 1) Keadilan distributif (distributive justice), adalah keadilan yang dirasakan berdasarkan alokasi penghargaan yang mereka terima dari organisasi. Indikator ini diukur dari persepsi responden mengenai keadilan yang dirasakan berdasarkan alokasi penghargaan yang diterima dari perusahaan. 2) Keadilan prosedural (procedural justice), yaitu keadilan yang dirasakan dari suatu prosedur atau aturan yang digunakan untuk menentukan setiap tahap prosedural kerja dalam perusahaan. Indikator ini diukur dari persepsi responden mengenai prosedur yang mengatur sistem kerja dalam perusahaan 3) Keadilan interaksional (interactional justice), merupakan keadilan yang dirasakan pada derajat penerimaan yang salah satunya diperlakukan dengan rasa hormat oleh 
pemimpin. Indikator ini diukur dari persepsi responden mengenai cara pemimpin memperlakukan karyawan dengan hormat.

Kepercayaan dalam penelitian ini adalah suatu harapan positif bahwa orang lain tidak akan bertindak secara oportunistik. Terdapat lima indikator utama yang membentuk konsep kepercayaan yaitu): 1) Integritas, yaitu keyakinan bahwa organisasi akan melakukan apa yang telah dijanjikan untuk dilakukan dan akan bertindak tanpa kontradiksi. Indikator ini diukur dari persepsi responden mengenai keyakinan bahwa perusahaan tidak akan bertindak kontradiksi. 2) Kompetensi, merupakan kemampuan yang dimiliki individu sesuai dengan kebutuhan perusahaan. Indikator ini diukur dari persepsi responden berdasarkan kesesuain kemampuan yang dimiliki dengan kebutuhan perusahaan. 3) Konsistensi, memiliki arti bahwa seseorang dapat tetap diandalkan dalam mengatasi setiap persoalan. Indikator ini diukur dari persepsi responden yang dapat tetap diandalkan untuk mengatasi setiap persoalan. 4) Loyalitas, yaitu kesetiaan karyawan terhadap perusahaan sehingga memiliki keinginan kuat untuk mendukung perusahaan. Indikator ini diukur melalui persepsi responden mengenai kesetiaannya yang tinggi terhadap perusahaan. 5) Keterbukaan, berarti bahwa individu dan perusahaan saling berbagi informasi dengan bebas tanpa ada yang disembunyikan. Indikator ini diukur melalui persepsi responden atas sikap saling berbagi informasi dengan perusahaan tanpa ada yang disembunyikan.

Komitmen organisasi dalam penelitian ini merupakan keyakinan dan dukungan yang kuat terhadap nilai dan tujuan yang ingin dicapai oleh organisasi (Harper, 2015). Indikator komitmen organisasi dalam penelitian ini: 1) Komitmen afektif (affective commitment), yaitu perasaan setia pada perusahaan karena memang begitu keinginan mereka yang sebenarnya ada dalam hati mereka. Indikator ini diukur melalui persepsi responden tentang perasaan setia yang dimiliki pada perusahaan secara sukarela. 2) Komitmen berkelanjutan (continuance commitment), merupakan kesadaran karyawan bahwa ia akan mengalami kerugian jika meninggalkan perusahaan. Indikator ini diukur dari persepsi responden tentang kesadaran akan kerugian jika meninggalkan perusahaan. 3) Komitmen normatif (normative commitment), merupakan rasa keterikatan untuk terus bertahan di perusahaan yang mempekerjakannya. Indikator ini dapat diukur dari persepsi responden tentang rasa keterikatan untuk terus bertahan dalam perusahaan.

Data yang digunakan dalam penelitian ini adalah jumlah karyawan dan data yang langsung didapat dari karyawan dengan cara penyebaran kuesioner berupa skor jawaban kuisioner. Data yang digunakan dalam penelitian ini adalah sejarah singkat organisasi, struktur, dan uraian tugas. Sumber primer dalam penelitian ini diperoleh dari jawaban responden melalui kuisioner yang disebarkan kepada responden. Sumber sekunder dalam penelitian ini adalah data mengenai gambaran umum perusahaan serta buku-buku dan artikel yang berkaitan dengan pembahasan pada penelitian ini. Populasi penelitian ini adalah seluruh karyawan yang ada di Impiana Private Villas Seminyak dengan jumlah 145 karyawan. Jumlah sampel yang didapat adalah 106 responden. Metode pengumpulan data yang digunakan dalam penelitian ini adalah Wawancara dan Kuesioner 


\section{HASIL DAN PEMBAHASAN}

Berawal dari visi seniman Jim Elliot yang membangun villa pertamanya untuk dirinya sendiri, kemudian teman-temannya terkesan akan kenyamanan dan keunikkan dam memintanya untuk membangun villa-villa yang lain untuk mereka. Ketika mulai disewakan untuk para teman dan kolega, tersebar mengenai citra villa dari mulut ke mulut sehingga banyak sekali orang yang berminat untuk menyewa villa tersebut. Atas permintaan tersebut lahirlah The Villas pada 15 Desember 1999.

Impiana Private Villas Seminyak pada awalnya merupakan The Villas Bali Hotel \& Spa, yang telah dibeli oleh Impiana Hotels, Resorts \& Spa pada Maret 2016 dan menjadi property Impiana pertama di Indonesia. Berkantor pusat di Malaysia, Impiana Private Villas Seminyak mengangkat gaya desain tropis berpadu dengan kontemporer Bali hadir dengan sentuhan modern. Beragam hidangan yang tersedia dipersiapkan oleh Restoran Prana yang telah meraih beberapa penghargaan restoran terbaik di Indonesia. Selain itu, kebanggan dari Impiana Private Villas Seminyak adalaha Prana Spa, yaitu salah satu spa terbesar di Bali yang juga memenangkan banyak penghargaan. Juga disediakan untuk para tamu yang lelah setelah berkeliling seminyak yaitu Chill Reflexology dengan gaya Zen yang minimalis dan memberi kesan rileks.

Tabel 1.

Karakteristik Responden Karyawan Impiana Private Villas Seminyak

\begin{tabular}{cccc}
\hline No & Jenis Kelamin & Jumlah $($ Orang) & Persentase (\%) \\
\hline $\mathbf{1}$ & Laki-laki & 55 & 51,9 \\
$\mathbf{2}$ & Perempuan & 51 & 48,1 \\
& Jumlah & $\mathbf{1 0 6}$ & $\mathbf{1 0 0}$ \\
No & Usia & Jumlah $($ Orang) & Persentase (\%) \\
$\mathbf{1}$ & $22-29$ tahun & 18 & 17 \\
$\mathbf{2}$ & $30-37$ tahun & 37 & 34,9 \\
$\mathbf{3}$ & $38-45$ tahun & 33 & 31,1 \\
$\mathbf{4}$ & $>45$ tahun & 18 & 17 \\
& Jumlah & $\mathbf{1 0 6}$ & $\mathbf{1 0 0}$ \\
No & Pendidikan Terakhir & Jumlah $($ Orang) & Persentase (\%) \\
$\mathbf{1}$ & SMA/SMK & 52 & 49,1 \\
$\mathbf{2}$ & Diploma & 41 & 38,7 \\
$\mathbf{3}$ & S1 & 13 & 12,3 \\
& Jumlah & $\mathbf{1 0 6}$ & $\mathbf{1 0 0}$ \\
No & Masa Kerja & Jumlah $($ Orang) & Persentase (\%) \\
$\mathbf{1}$ & $<5$ tahun & 26 & 24,5 \\
$\mathbf{2}$ & 5-10 tahun & 21 & 19,8 \\
$\mathbf{3}$ & $10-15$ tahun & 38 & 35,8 \\
$\mathbf{4}$ & $>15$ tahun & 21 & 19,8 \\
& Jumlah & $\mathbf{1 0 6}$ & $\mathbf{1 0 0}$ \\
\hline
\end{tabular}

Sumber: Data diolah, 2019

Berdasarkan Tabel 1. Penglompokan responden berdasarkan jenis kelamin menunjukkan bahwa jumlah responden laki-laki sebesar 51,9 persen dan responden 
perempuan sebesar 48,1 persen. Hal ini menunjukkan bahwa Impiana memiliki karyawan yang berjenis kelamin laki-laki lenih banyak. Karena pada saat perekrutan/penerimaan rata-rata karyawan yang diterima berjenis kelamin laki-laki. Berdasarkan usianya responden dengan usia 30 tahun ke atas memiliki skor terbanyak dan usia dibawah 30 sangat sedikit. Hal ini menunjukkan bahwa karyawan Impiana rata-rata berusia 30 tahun ke atas. Dikarenakan para karywan yang berusia 30 tahun ke atas merupakan karyawan tetap dari Impiana Privet Villas Seminyak yang telah bekerja dari awal perusahaan dibuka dan masih bertahan hingga sekarang.

Selain itu penglompokan responden berdasarkan pendidikan terakhir, responden lulusan SMA/SMK memiliki skor yang paling besar. Berdasarkan pernyataan diatas dapat dikatakan bahwa rata-rata karyawan yang bekerja di Impiana Privet Villas Seminyak hanya lulusan SMA/SMK. Hal ini dikarenakan pada saat awal Impiana Privet Villas Seminyak melakukan perekrutan karyawan, lebih banyak yang melamar hanya dengan lulusan SMA/SMK, karena lulusan sarjana masih sangat jarang. Berdasarkan masa kerja, sebagian besar responden memiliki masa kerja 10 tahun ke atas, dan yang dibawah 5 tahun hanya sedikit. Artinya, karyawan yang masa kerja nya lebih dari 10 tahun lebih mempunyai pengalaman dan pengetahuan sehingga masih bekerja sampai sekarang di Impiana Privet Villas Seminyak. Serta mereka sudah banyak mengetahui kondisi riil persoalan-persoalan yang terjadi di dalam perusahaan.

Tabel 2.

Hasil Uji Validitas Instrumen Penelitian

\begin{tabular}{lcc}
\hline \multicolumn{1}{c}{ Variabel } & Indikator & Koefisien Korelasi \\
\hline Organizational Citizenship & Y1 & 0,503 \\
Behavior & Y2 & 0,777 \\
(Y) & Y3 & 0,845 \\
& Y4 & 0,738 \\
Keadilan Organisasional & Y5 & 0,785 \\
(X1) & X1.1 & 0,923 \\
& X1.2 & 0,898 \\
Trust & X1.3 & 0,804 \\
(X2) & X2.1 & 0,673 \\
& X2.2 & 0,753 \\
& X2.3 & 0,759 \\
Komitmen Organisasional (X3) & X2.4 & 0,779 \\
& X2.5 & 0,881 \\
& X3.1 & 0,843 \\
& X3.2 & 0,955 \\
\hline
\end{tabular}

Sumber: Data diolah, 2019

Hasil uji validitas pada Tabel 2. menunjukkan bahwa seluruh instrumen penelitian yang digunakan untuk mengukur variabel organizational citizenship behavior, keadilan organisasional, trust, dan komitmen organisasional memiliki nilai koefisien korelasi dengan skor total seluruh item pernyataan lebih dari 0,30. Hal ini menunjukkan bahwa butir-butir pernyataan dalam instrumen penelitian tersebut valid dan layak digunakan sebagai instrumen penelitian. 
Tabel 3.

Hasil Uji Reliabilitas Instrumen Penelitian

\begin{tabular}{ccc}
\hline No & Variabel & Cronbach's Alpha \\
\hline 1 & Organizational Citizenship Behavior & 0,762 \\
2 & Keadilan Organisasional & 0,848 \\
3 & Trust & 0,823 \\
4 & Komitmen Organisasional & 0,896 \\
\hline
\end{tabular}

Sumber: Data diolah, 2019

Hasil uji reliabilitas yang disajikan dalam Tabel 3. menunjukkan bahwa seluruh instrumen penelitian memiliki koefisien Cronbach's Alpha lebih dari 0,60. Jadi dapat dinyatakan bahwa seluruh variabel telah memenuhi syarat reliablitas atau kehandalan sehingga dapat digunakan untuk melakukan penelitian

Tabel 4.

Deskripsi Jawaban Responden terhadap Indikator Organizational Citizenship Behavior

\begin{tabular}{|c|c|c|c|c|c|c|c|c|}
\hline \multirow[t]{2}{*}{ No. } & \multirow[t]{2}{*}{ Pernyataan } & \multicolumn{5}{|c|}{$\begin{array}{c}\text { Frekuensi Jawaban } \\
\text { Responden }\end{array}$} & \multirow{2}{*}{$\begin{array}{l}\text { Rata- } \\
\text { Rata }\end{array}$} & \multirow[t]{2}{*}{ Ket. } \\
\hline & & STS & TS & $\mathbf{C S}$ & $\mathbf{S}$ & SS & & \\
\hline & Saya dengan rela menolong rekan & & & & & & & \\
\hline 1 & $\begin{array}{l}\text { kerja tanpa mengharapkan } \\
\text { imbalan. }\end{array}$ & 0 & 2 & 13 & 54 & 37 & 4.19 & Tinggi \\
\hline 2 & $\begin{array}{l}\text { Saya melakukan pekerjaan } \\
\text { melebihi deskripsi yang telah } \\
\text { ditetapkan perusahaan. }\end{array}$ & 0 & 5 & 25 & 60 & 16 & 3.82 & Tinggi \\
\hline 3 & $\begin{array}{l}\text { Saya menjaga baik hubungan } \\
\text { dengan rekan kerja untuk } \\
\text { menghindari masalah } \\
\text { interpersonal }\end{array}$ & 0 & 1 & 10 & 57 & 38 & 4.25 & $\begin{array}{l}\text { Sangat } \\
\text { tinggi }\end{array}$ \\
\hline 4 & $\begin{array}{l}\text { Saya memiliki kemampuan } \\
\text { beradaptasi dengan lingkungan } \\
\text { kerja. }\end{array}$ & 0 & 1 & 17 & 54 & 34 & 4.14 & Tinggi \\
\hline 5 & $\begin{array}{l}\text { Saya selalu berpartisipasi secara } \\
\text { penuh dalam setiap kegiatan yang } \\
\text { diselenggarakan perusahaan }\end{array}$ & 0 & 1 & 18 & 55 & 32 & 4.11 & Tinggi \\
\hline \multicolumn{7}{|c|}{ Rata-rata keseluruhan variabel organizational citizenship behavior } & 4,10 & Tinggi \\
\hline
\end{tabular}

Sumber: Data diolah, 2019

Tabel 4. menunjukkan bahwa rata-rata skor dari 5 pernyataan mengenai organizational citizenship behavior sebesar 4,10 mendapatkan hasil yang tinggi. Secara keseluruhan responden setuju bahwa sikap OCB yang dimiliki oleh karyawan Impiana Private Villas tinggi. Jika dilihat secara parsial, nilai rata-rata jawaban tertinggi responden diperoleh oleh pernyataan "Saya menjaga baik hubungan dengan rekan kerja untuk menghindari masalah interpersonal" memiliki penilaian tertinggi dengan rata-rata 4,25. Hal ini menunjukkan bahwa sebagian besar karyawan menjaga hubungan baik dengan karyawan lainnya. Kemudian penilaian terendahnya terdapat pada pernyataan "Saya melakukan pekerjaan 
melebihi deskripsi yang telah ditetapkan perusahaan.”, dengan skor rata-rata sebesar 3,82. Hal ini menunjukkan bahwa sebagian karyawan tidak memiliki inisiatif untuk melakukan pekerjaan lain diluar deskripsi pekerjaannya yang telah ditetapkan.

Tabel 5. menunjukkan bahwa rata-rata skor dari 3 pernyataan mengenai keadilan organisasional sebesar 3,95 yang berarti tinggi. Secara keseluruhan responden setuju bahwa Impiana Private Villas sudah adil dalam memperlakukan karyawannya. Jika dilihat secara parsial, pernyataan "Pemimpin memperlakukan saya dengan hormat." memiliki penilaian tertinggi dengan rata-rata 3,97. Hal ini menunjukkan bahwa karyawan telah merasa diperlakukan dengan hormat oleh atasan mereka. Kemudian pada pernyataan "Saya merasa prosedur yang mengatur sistem kerja dalam perusahaan sudah cukup adil" dan dengan skor rata-rata sebesar 3,93. Hal ini menunjukkan kurangnya alokasi penghargaan yang diberikan oleh perusahaan untuk para karyawan.

Tabel 5.

Deskripsi Penilaian Responden terhadap Variabel Keadilan Organisasional

\begin{tabular}{|c|c|c|c|c|c|c|c|c|}
\hline \multirow{2}{*}{ No. } & \multirow{2}{*}{ Pernyataan } & \multicolumn{5}{|c|}{ Frekuensi Jawaban Responden } & \multirow{2}{*}{$\begin{array}{l}\text { Rata- } \\
\text { rata }\end{array}$} & \multirow{2}{*}{ Ket. } \\
\hline & & STS & TS & $\mathbf{C S}$ & $\mathbf{S}$ & SS & & \\
\hline 1 & $\begin{array}{l}\text { Saya merasa alokasi penghargaan } \\
\text { dari perusahaan sudah adil }\end{array}$ & 0 & 5 & 22 & 53 & 26 & 3.94 & Tinggi \\
\hline 2 & $\begin{array}{l}\text { Saya merasa prosedur yang } \\
\text { mengatur sistem kerja dalam } \\
\text { perusahaan sudah cukup adil }\end{array}$ & 0 & 4 & 27 & 47 & 28 & 3.93 & Tinggi \\
\hline 3 & $\begin{array}{l}\text { Pemimpin memperlakukan saya } \\
\text { dengan hormat. }\end{array}$ & 0 & 1 & 28 & 50 & 27 & 3.97 & Tinggi \\
\hline \multicolumn{7}{|c|}{ Rata-rata keseluruhan variabel keadilan organisasional } & 3.95 & Tinggi \\
\hline
\end{tabular}

Sumber: Data diolah, 2019

Tabel 6. menunjukkan bahwa rata-rata skor dari 5 pernyataan mengenai trust atau kepercayaan sebesar 3,95 yang tergolong tinggi. Secara keseluruhan responden setuju bahwa Impiana Private Villas Seminyak mempercayai seluruh karyawannya untuk mampu menjalankan pekerjaan dengan baik. Jika dilihat secara parsial, pernyataan "Perusahaan mempercayai kemampuan yang saya miliki sesuai dengan kebutuhan perusahaan" memiliki penilaian tertinggi dengan rata-rata 4,12. Hal ini menunjukkan bahwa sebagian besar karyawan dapat dipercaya oleh perusahaan memiliki kemampuan sesuai dengan bidang pekerjaannya. Kemudian penilaian terendahnya terdapat pada pernyataan "Saya memiliki keyakinan bahwa perusahaan tidak akan bertindak kontradiksi", dengan skor rata-rata sebesar 3,71. Yang menunjukkan bahwa karyawan merasa perusahaan telah bertindak kontradiksi. 
Tabel 6.

Deskripsi Penilaian Responden terhadap Variabel Trust

\begin{tabular}{|c|c|c|c|c|c|c|c|c|}
\hline \multirow{2}{*}{ No. } & \multirow{2}{*}{ Pernyataan } & \multicolumn{5}{|c|}{ Frekuensi Jawaban Responden } & \multirow{2}{*}{$\begin{array}{l}\text { Rata- } \\
\text { Rata }\end{array}$} & \multirow{2}{*}{ Ket. } \\
\hline & & STS & TS & CS & $\mathbf{S}$ & SS & & \\
\hline 1 & $\begin{array}{l}\text { Saya memiliki keyakinan } \\
\text { bahwa perusahaan tidak akan } \\
\text { bertindak kontradiksi }\end{array}$ & 0 & 3 & 33 & 62 & 8 & 3.71 & Tinggi \\
\hline 2 & $\begin{array}{l}\text { Perusahaan mempercayai } \\
\text { kemampuan yang saya miliki } \\
\text { sesuai dengan kebutuhan } \\
\text { perusahaan. }\end{array}$ & 0 & 0 & 18 & 57 & 31 & 4.12 & Tinggi \\
\hline 3 & $\begin{array}{l}\text { Perusahaan dapat tetap } \\
\text { mengandalkan saya dalam } \\
\text { mengatasi setiap persoalan. }\end{array}$ & 0 & 1 & 22 & 55 & 28 & 4.04 & Tinggi \\
\hline 4 & $\begin{array}{l}\text { Saya memiliki kesetiaan yang } \\
\text { tinggi terhadap perusahaan. }\end{array}$ & 0 & 0 & 24 & 60 & 22 & 3.98 & Tinggi \\
\hline 5 & $\begin{array}{l}\text { Saya dan perusahaan saling } \\
\text { berbagi informasi tanpa ada yang } \\
\text { disembunyikan }\end{array}$ & 0 & 1 & 28 & 58 & 19 & 3.90 & Tinggi \\
\hline \multicolumn{7}{|c|}{ Rata-rata keseluruhan variabel trust } & 3,95 & Tinggi \\
\hline
\end{tabular}

Sumber: Data diolah, 2019

Tabel 7.

Deskripsi Penilaian Responden terhadap Variabel Komitmen Organisasional

\begin{tabular}{|c|c|c|c|c|c|c|c|c|}
\hline \multirow[t]{2}{*}{ No. } & \multirow[t]{2}{*}{ Pernyataan } & \multicolumn{5}{|c|}{$\begin{array}{c}\text { Frekuensi Jawaban } \\
\text { Responden }\end{array}$} & \multirow{2}{*}{$\begin{array}{l}\text { Rata- } \\
\text { rata }\end{array}$} & \multirow[t]{2}{*}{ Ket. } \\
\hline & & STS & TS & CS & $\mathbf{S}$ & SS & & \\
\hline 1 & $\begin{array}{l}\text { Saya memiliki perasaan setia } \\
\text { pada perusahaan }\end{array}$ & 0 & 2 & 27 & 54 & 23 & 3.92 & Tinggi \\
\hline 2 & $\begin{array}{l}\text { Saya merasa akan mengalami } \\
\text { kerugian jika saya meninggalkan } \\
\text { perusahaan }\end{array}$ & 0 & 8 & 29 & 56 & 13 & 3.70 & Tinggi \\
\hline 3 & $\begin{array}{l}\text { Saya memiliki perasaan terikat } \\
\text { untuk terus bertahan dalam } \\
\text { perusahaan }\end{array}$ & 0 & 5 & 30 & 48 & 23 & 3.84 & Tinggi \\
\hline \multicolumn{7}{|c|}{ Rata-rata keseluruhan variabel komitmen organisasional } & 3.82 & Tinggi \\
\hline
\end{tabular}

Sumber: Data diolah, 2019

Tabel 7. menunjukkan bahwa rata-rata skor dari 3 pernyataan mengenai motivasi berwirausaha sebesar 3,82 yang digolongkan tinggi. Secara keseluruhan yang responden setuju bahwa karyawan berkomitmen tinggi terhadap perusahaanya yaitu Impiana Private Vilas Seminyak. Jika dilihat secara parsial, pernyataan "Saya memiliki perasaan setia pada perusahaan" memiliki penilaian tertinggi dengan rata-rata 3,92. Hal ini menunjukkan bahwa sebagian karyawan memiliki rasa setia kepada perusahaan sehingga menimbulkan komitmen yang tinggi terhadap perusahaan. Kemudian penilaian terendahnya terdapat pada pernyataan "Saya merasa akan mengalami kerugian jika saya meninggalkan perusahaan", dengan 
skor rata-rata sebesar 3,70. Hal ini menunjukkan bahwa sebagian besar karyawan merasa tidak akan mengalami kerugian jika meninggalkan perusahaan.

Tabel 8.

Hasil Analisis Regresi Linier Berganda

\begin{tabular}{lccccc}
\hline \multirow{1}{*}{ Model } & \multicolumn{2}{c}{$\begin{array}{c}\text { Unstandardized } \\
\text { Coefficients }\end{array}$} & $\begin{array}{c}\text { Standardized } \\
\text { Coefficients }\end{array}$ & t & \multirow{2}{*}{ Sig. } \\
\cline { 2 - 4 } & $\mathbf{B}$ & Std. Error & Beta & & \\
\hline (Constant) & 1,041 & 0,225 & & 4,085 & 0,000 \\
Keadilan & 0,339 & 0,057 & 0,440 & 5,953 & 0,000 \\
Organisasional & 0,268 & 0,088 & 0,262 & 3,046 & 0,003 \\
Trust & 0,173 & 0,065 & 0,230 & 2,659 & 0,009 \\
Komitmen & & & & \\
Organisasional & &
\end{tabular}

Sumber: Data diolah, 2019

Nilai koefisien variabel keadilan oganisasional $\left(\mathrm{X}_{1}\right)$ sebesar 0,440 , berarti terdapat hubungan positif antara keadilan oganisasional dan organizational citizenship behavior (Y). Sehingga dapat disimpulkan bahwa keadilan organisasional berpengaruh positif terhadap organizational citizenship behavior pada karyawan Impiana Private Villas Seminyak. Nilai koefisien variabel trust $\left(\mathrm{X}_{2}\right)$ sebesar 0,262 , berarti terdapat hubungan positif antara trust dan organizational citizenship behavior (Y). Sehingga dapat disimpulkan bahwa trust berpengaruh positif terhadap organizational citizenship behavior pada karyawan Impiana Private Villas Seminyak. Nilai koefisien variabel komitmen oganisasional $\left(\mathrm{X}_{3}\right)$ sebesar 0,230 berarti terdapat hubungan positif antara komitmen oganisasional dan organizational citizenship behavior (Y). Sehingga dapat disimpulkan bahwa komitmen oganisasional berpengaruh positif terhadap organizational citizenship behavior pada karyawan Impiana Private Villas Seminyak.

Tabel 9.

Hasil Uji Normalitas

\begin{tabular}{cc}
\hline & Unstandardized Residual \\
\hline $\mathrm{N}$ & 106 \\
Kolmogorov-Smirnov Z & 0,613 \\
Asymp. Sig. (2-tailed). & 0,846 \\
\hline
\end{tabular}

Sumber: Data diolah, 2019

Berdasarkan Tabel 9. dapat diketahui bahwa asymp.Sig (2-tailed). Sebesar 0,846 yaitu lebih besar dari $0,05(0,846>0,05)$. Dengan demikian data tersebut dinyatakan berdistribusi normal.

Tabel 10. menunjukkan nilai tolerance dan VIF dari variabel keadilan organisasional, trust, dan komitmen organisasional. Berdasarkan hasil analisis, dapat dilihat bahwa koefisien tolerance seluruh variabel lebih besar dari 0,10 dan nilai VIF lebih kecil dari 10. Hasil ini mengindikasikan bahwa tidak terdapat gejala multikolinearitas. 
Tabel 10.

Hasil Uji Multikolinearitas

\begin{tabular}{lcc}
\hline \multirow{2}{*}{ Model } & \multicolumn{2}{c}{ Colinearity Statistic } \\
\cline { 2 - 3 } & Tolerance & VIF \\
\hline Keadilan Organisasional $\left(\mathrm{X}_{1}\right)$ & 0,666 & 1,501 \\
Trust $\left(\mathrm{X}_{2}\right)$ & 0,494 & 2,026 \\
Komitmen Organisasional $\left(\mathrm{X}_{3}\right)$ & 0,486 & 2,056 \\
\hline
\end{tabular}

Sumber: Data diolah, 2019

Tabel 11.

Hasil Uji Heteroskedastisitas

\begin{tabular}{lccccc}
\hline \multirow{1}{*}{ Model } & \multicolumn{2}{c}{$\begin{array}{c}\text { Unstandardized } \\
\text { Coefficients }\end{array}$} & $\begin{array}{c}\text { Standardized } \\
\text { Coefficients }\end{array}$ & t & \multirow{2}{*}{ Sig. } \\
\cline { 2 - 4 } & B & Std. Error & Beta & & \\
\hline (Constant) & 0,397 & 0,149 & & 2,663 & 0,009 \\
Keadilan & $-0,012$ & 0,033 & $-0,42$ & $-0,349$ & 0,728 \\
Organisasional & 0,026 & 0,052 & 0,70 & 0,505 & 0,615 \\
Trust & $-0,054$ & 0,038 & $-0,196$ & $-1,403$ & 0,164 \\
Komitmen & Organisasional & & & & \\
\hline
\end{tabular}

Sumber: Data diolah, 2019

Tabel 11. menunjukkan bahwa nilai Sig. dari variabel keadilan organisasional, trust, dan komitmen organisasional.lebih dari 0,05 yang artinya model regresi bebas dari gejala heteroskedastisitas.

Tabel 12.

Hasil Analisis Koefisien Determinasi $\left(\mathbf{R}^{2}\right)$

\begin{tabular}{cccc}
\hline $\mathbf{R}$ & R Square & Adjusted R Square & Std. Error of the Estimate \\
\hline $0,793^{\mathrm{a}}$ & 0,628 & 0,617 & 0,316989 \\
\hline
\end{tabular}

Sumber: Data diolah, 2019

Berdasarkan hasil uji pada tabel 12 nilai $R$ Square sebesar 0,628. Sehingga dapat dihitung persentase kontribusi keadilan organisasional, trust, dan komitmen organisasional terhadap organizational citizenship behavior sebesar 0,628 $\times 100$ persen $=62,8$ persen dan sisanya 37,2 persen dipengaruhi oleh variabel lain diluar penelitian.

Tabel 13.

Hasil Hasil Uji F (Uji Kelayakan Model)

\begin{tabular}{lccccc}
\hline \multicolumn{1}{c}{ Model } & $\begin{array}{c}\text { Sum of } \\
\text { squares }\end{array}$ & Df & $\begin{array}{c}\text { Mean } \\
\text { square }\end{array}$ & F & Sig. \\
\hline Regression & 17,297 & 3 & 5,766 & 57,415 & $.000^{\text {a }}$ \\
Residual & 10,243 & 102 & 0.100 & & \\
Total & 27,540 & 105 & & & \\
\hline
\end{tabular}

Sumber: Data diolah, 2019 
Tabel 13. menunjukkan nilai sig sebesar 0,000 yang lebih kecil dari 0,05 (sig $<\alpha$ ) yang berarti variabel bebas yaitu keadilan organisasional $\left(\mathrm{X}_{1}\right)$, trust $\left(\mathrm{X}_{2}\right)$, komitmen organisasional $\left(\mathrm{X}_{3}\right)$ berpengaruh signifikan secara serempak atau bersama-sama terhadap variabel terikat yaitu organizational citizenship behavior (Y), sehingga penelitian ini dapat dikatakan memenuhi uji kelayakan model atau model penelitian ini dinyatakan layak digunakan sebagai model regresi.

Berdasarkan hasil regresi linier berganda diketahui bahwa nilai koefisien beta variabel keadilan organisasional bernilai positif yakni 0,440 dengan nilai sig sebesar 0,000. Nilai Sig. 0,000 $<0,05$ mengindikasikan bahwa $\mathrm{H}_{1}$ diterima. Dengan kata lain keadilan organisasional berpengaruh positif dan signifikan terhadap organizational citizenship behavior. Nilai koefisien beta variabel trust bernilai positif yakni 0,262 dengan nilai sig sebesar 0,003. Nilai Sig. 0,003 < 0,05 mengindikasikan bahwa $\mathrm{H}_{1}$ diterima. Dengan kata lain trust berpengaruh positif dan signifikan terhadap organizational citizenship behavior. Nilai koefisien beta variabel komitmen organisasional bernilai positif yakni 0,230 dengan nilai sig sebesar 0,009. Nilai Sig. 0,009 < 0,05 mengindikasikan bahwa $\mathrm{H}_{1}$ diterima. Dengan kata lain komitmen organisasional berpengaruh positif dan signifikan terhadap organizational citizenship behavior

Berdasarkan pengujian hipotesis variabel keadilan organisasional terhadap organizational citizenship behavior bahwa dalam penelitian ini mendapatkan hasil $\mathrm{H}_{0}$ ditolak dan $\mathrm{H}_{1}$ diterima. Menunjukkan bahwa keadilan organisasional berpengaruh positif dan signifikan terhadap organizational citizenship behavior. Artinya semakin tinggi keadilan organisasional yang dirasakan oleh para karyawan maka semakin timggi juga organizational citizenship behavior karyawan Impiana Private Villas Seminyak. Hal ini sesuai dengan penilaian responden terhadap variabel keadilan organisasional yang mendapatkan rata-rata sebesar 3,95 dengan kategori tinggi. Dalam hal ini, perilaku OCB karyawan Impiana Private Villas Seminyak sebagian besar disebabkan oleh sikap pemimpin yang memperlakukan karyawan dengan hormat dan alokasi penghargaan dari perusahaan sudah adil. Hasil penelitian ini mendukung temuan dari Nandan \& Abdul (2015), Nwibere (2015) yang menunjukkan bahwa persepsi karyawan tentang keadilan mempunyai pengaruh positif dan signifikan terhadap OCB. Penemuan serupa juga dilakukan oleh Ibrahim \& Ann (2015), Mustafa et al. (2016) dan Demirel et al. (2018) yang mengungkapkan hubungan positif dan signifikan antara keadilan organisasional dan organizational citizenship behavior.

Berdasarkan pengujian hipotesis variabel trust terhadap organizational citizenship behavior menyatakan bahwa dalam penelitian ini mendapatkan hasil $\mathrm{H}_{0}$ ditolak dan $\mathrm{H}_{1}$ diterima. Menunjukkan bahwa trust berpengaruh positif dan signifikan terhadap organizational citizenship behavior. Artinya semakin tinggi trust yang dimiliki karyawan maka akan semakin tinggi organizational citizenship behavior para karyawan Impiana Private Villas Seminyak. Hal ini sesuai dengan penilaian responden terhadap variabel trust yang mendapatkan rata-rata sebesar 3,95 dengan kategori tinggi Dalam hal ini, perilaku OCB karyawan Impiana Private Villas Seminyak sebagian besar disebabkan oleh kepercayaan yang diberikan perusahaan atas kemampuan yang dimiliki setiap karyawan sesuai dengan kebutuhan perusahaan. Hasil penelitian ini mendukung temuan dari Makhdoom et 
al. (2016), Suyono \& Sunaryo (2015), Singh \& Srivastava (2016) yang menyatakan bahwa trust (kepercayaan) memiliki pengaruh yang positif terhadap OCB. Hasil dari penelitian Pourkeiani et al. (2016) dan Leelamanothum et al. (2018) mengemukakan bahwa trust berpengaruh secara signifikan dan positif terhadap organizational citizenship behavior.

Berdasarkan pengujian hipotesis variabel komitmen organisasional terhadap organizational citizenship behavior menyatakan bahwa dalam penelitian ini mendapatkan hasil $\mathrm{H}_{0}$ ditolak dan $\mathrm{H}_{1}$ diterima. Menunjukkan bahwa komitmen organisasional berpengaruh positif dan signifikan terhadap organizational citizenship behavior. Hal ini berarti semakin tinggi komitmen organisasional yang dimiliki karyawan maka semakin tinggi juga organizational citizenship behavior karyawan Impianan Private Villas Seminyak. Hal ini sesuai dengan penilaian responden terhadap variabel keadilan organisasional yang mendapatkan rata-rata sebesar 3,82 dengan kategori tinggi. Dalam hal ini, perilaku OCB karyawan Impiana Private Villas Seminyak sebagian besar disebabkan oleh perasaan setia yang dimiliki karyawan pada perusahaan dan perasaan terikat untuk terus bertahan dalam perusahaan. Hasil penelitian ini mendukung temuan dari Günay (2018) dan Diatmika \& Suwandana (2016) menunjukkan bahwa komitmen organisasional berpengaruh positif dan signifikan terhadap organizational citizenship behavior. Begitu juga dengan penelitian yang dilakukan oleh Asiedu et al. (2015), dan Ferdus \& Kabir (2018) bahwa komitmen organisasional berpengaruh secara positif dan signifikan dengan organizational citizenship behavior.

Hasil penelitian ini memiliki implikasi teoritis dan praktis. Secara teoritis penelitian ini menunjukan bahwa keadilan organisasional, trust, dan komitmen organisasional berpengaruh positif dan signifikan terhadap organizational citizenship behavior. Dengan demikian hasil penelitian ini memberikan dukungan empiris dan dapat dinyatakan memperkuat hasil-hasil studi terdahulu. Secara praktis penelitian ini diharapkan dapat menjadi bahan pertimbangan dan informasi kepada Impiana Private Villas Seminyak untuk meningkatkan keadilan, trust, dan komitmen dalam perusahaan guna terciptanya perilaku OCB yang lebih tinggi lagi.

Faktor-faktor yang mempengaruhi organizational citizenship behavior dalam penelitian ini hanya terdiri dari tiga variabel, yaitu keadilan organisasional, trust, dan komitmen organisasional. Sedangkan masih banyak faktor lain yang mempengaruhi organizational citizenship behavior. Lokasi penelitian ini hanya dilakukan di Impiana Private Villas Seminyak sedangkan masih banyak perusahaan lainnya. Sehingga diharapkan untuk selanjutnya agar bisa dilaksanakan di lokasi yang berbeda.

\section{SIMPULAN}

Keadilan organisasional berpengaruh positif dan signifikan terhadap OCB karyawan di Impiana Private Villas Seminyak. Hal ini menunjukkan bahwa semakin tinggi keadilan organisasional yang diberikan perusahaan maka OCB pada karyawan juga akan semakin meningkat. Trust berpengaruh positif dan signifikan terhadap terhadap OCB karyawan di Impiana Private Villas 
Seminyak. Hal ini menunjukkan bahwa semakin tinggi trust yang diberikan perusahaan maka OCB pada karyawan juga akan semakin meningkat. Komitmen organisasional berpengaruh positif dan signifikan terhadap OCB karyawan di Impiana Private Villas Seminyak. Hal ini menunjukkan bahwa semakin tinggi komitmen organisasional yang dimiliki karyawan maka OCB pada karyawan juga akan semakin meningkat

Pihak Impiana Private Villas Seminyak diharapkan dapat meningkatkan perilaku OCB seluruh karyawan. Menurut hasil penelitian, indikator "saya melakukan pekerjaan melebihi deskripsi yang telah ditetapkan" memiliki nilai ratarata terendah. Perusahaan dapat membangun rasa memiliki pada karyawan, membangun hubungan yang baik antara karyawan dengan atasan maupun perusahaan. Dengan begitu maka karyawan akan merasa bertanggung jawab pada perusahaan dan akan mau melakukan pekerjaan diluar deskripsi yang telah ditetapkan.

Pihak Impiana Private Villas Seminyak diharapkan mampu menerapkan keadilan bagi seluruh karyawan. Karena berdasarkan hasil penelitian, pernyataan "prosedur yang mengatur sistem kerja di perusahaan sudah cukup adil" mendapatkan nilai rata-rata terendah. Hal tersebut mengindikasi bahwa sistem kerja yang diterapkan oleh perusahaan tidak cukup adil bagi karyawan. Hendaknya perusahaan merevisi prosedur kerja tersebut dengan mengumpulkan pendapat karyawan mengenai prosedur yang adil dan menambahkan kritik dan saran dari para karyawan. Jika prosedur kerja disusun bersama dengan para karyawan maka mereka akan merasa puas dan hasil nya dianggap adil bagi seluruh karyawan.

Pihak Impiana Private Villas Seminyak harus lebih mampu membangun kepercayaan dengan para karyawan. Berdasarkan penelitian, pernyataan "saya memiiliki keyakinan bahwa perusahaan tidak akan bertindak kontradiksi" memiliki nilai rata-rata terendah. Cara perusahaan untuk meyakinkan karyawan dapat dilakukan dengan merevisi kontrak kerja yang didiskusikan dengan perwakilan karyawan. Maka karyawan akan percaya sepenuhnya bahwa perusahaan tidak akan bertindak kontradiksi.

Pihak Impiana Private Villas Seminyak perlu meningkatkan komitmen organisasional seluruh para karyawan. Hasil penelitian menunujukkan pernyataan "saya merasa akan mengalami kerugian jika meninggalkan perusahaan" mendapat nilai rata-rata terendah. Perusahaan harus menjalin hubungan yang baik dengan karyawan, sehingga mereka merasa diperlakukan dengan hormat. Juga mendapat hasil yang sesuai dengan kewajibannya, maka dengan begitu karyawan akan merasa rugi jika ia meninggalkan perusahaan.

\section{REFERENSI}

Asiedu, M., Sarfo, J. O., \& Adjei, D. (2015). Organisational Commitment and Citizenship Behaviour: Tools To Improve Employee Performance; An Internal Marketing Approach. European Scientific Journal, 10(4), 288-305.

Candika, J., \& Chairoel, L. (2018). Pengaruh keadilan organisasional terhadap komitmen organisasional melalui variabel intervening kepuasan kerja pada 
karyawan PT. Lembah Karet Padang. Jurnal Benefita, 3(2), 248-262.

Demirel, Y., Elhusadi, I., \& Alhasadi, A. (2018). The Relationship between Organizational Citizenship Behavior and Organizational Factors. International Journal of Business and Management Invention (IJBMI), 7(3), 27-39.

Diatmika, I. N. C. Y., \& Suwandana, I. (2016). Pengaruh Komitmen Organisasi dan Motivasi Kerja Terhadap Organizational Citizenship Behavior di Alam Puri. E-Jurnal Manajemen Unud, 5(11), 7128-7155.

Fard, P. G., \& Karimi, F. (2015). The Relationship between Organizational Trust and Organizational Silence with Job Satisfaction and Organizational Commitment of the Employees of University. International Education Studies, 8(11), 219-227.

Ferdus, Z., \& Kabir, T. (2018). Effect of Job Satisfaction and Organizational Commitment on OCB: Study on Private Banks in Bangladesh. World Journal of Social Sciences, 8(2), 57-69.

Firaz, C. (2015). Faktor-Faktor Yang Berhubungan Dengan Perilaku Kerja Karyawan Penderita Aging Disease Di PT Holcim Indonesia Tbk Cilacap Plant. Jurnal Kesehatan Masyarakat (e-Journal), 3(3), 877-886.

Gunastri, N. M., Handayani, A. A. I. R. E., \& Astakoni, I. M. P. (2019). Analisis Pengaruh Kepuasan Kerja Terhadap Organizational Citizenship Behavior (Ocb) Dengan Variabel Mediasi Komitmen Organisasional (Studi Pada Koperasi Asadana Semesta Denpasar). E-Jurnal Manajemen Universitas Udayana, 14(3), 1784. https://doi.org/10.24843/ejmunud.2019.v08.i03.p22

Günay, G. Y. (2018). Relationship between Job Satisfaction , Organizational Citizenship Behavior and Employee Performance : Sample of Edirne Financial Office Employees in Turkey. American International Journal of Contemporary Research, 8(1), 64-65.

Harper, P. J. (2015). Exploring forms of organizational citizenship behaviors (OCB): antecedents and outcome. Journal of Management and Marketing Research, 18(1), 1-16.

Ibrahim, M. E., \& Ann, O. P. (2015). Effects of organizational justice, employee satisfaction, and gender on employees' commitment: evidence from the use. International Journal of Business and Management, 9(2), 45-59.

Kristanto, H. (2015). Keadilan organisasional, komitmen organisasional, dan kinerja karyawan. Jurnal Manajemen Dan Kewirausahaan, 17(1), 86-98. 
Kurniawan, A. (2015). Pengaruh Komitmen Organisasi Terhadap Organizational Citizenship Behavior (OCB) PT X Bandung. Jurnal Manajemen, 15(1), 95118.

Lakshmi, P. A. V., \& Simarmata, N. (2015). Hubungan antara Iklim Organisasi dengan Perilaku Kewargaan Organisasi Pada Karyawan di Perusahaan Ritel. Jurnal Psikologi Udayana, 2(1), 25-37.

Leelamanothum, A., Na-Nan, K., \& Ngudgratoke, S. (2018). The Influences of Justice and Trust on the Organizational Citizenship Behavior of Generation X and Generation Y. Canadian Center of Science and Education, 14(5), 60-67.

Mada, I. G. N. W., Sintaasih, D. K., \& Subudi, M. (2017). Pengaruh keadilan organisasional terhadap motivasi dan kinerja karyawan. Forum Manajemen, 15(2), 1-18.

Makhdoom, H.-R., Anjum, A., Sabir, H. M., \& Khaliq, T. (2016). Impact of Organization Trust, Organization Justice and Job Satisfaction on Organization Citizenship Behavior: A study in Banking Sector of Pakistan. International Journal of Academic Research in Business and Social Sciences, 6(12), 630643. https://doi.org/10.6007/ijarbss/v6-i12/2525

Mustafa, D., Serap, T., \& Mehmet, D. (2016). A study on the relationship between organizational justice and organizational citizenship behavior in hospitals. International Journal of Business Management and Economic Research, 7(2), $547-554$.

Nandan, T., \& Abdul, M. M. A. (2015). Organizational Justice and Organizational Citizenship Behavior: Mediating Role of Psychological Capital. American International Journal of Social Science, 4(6), 148-156.

Nwibere, B. M. (2015). Organisational justice as a determinant of organisational citizenship behaviour in the nigerain work environment: a study of selected universities in the niger delta region. International Journal Of Business And Management, 9(4), 191-205.

Pourkeiani, M., \& Maryam Tanabandeh. (2016). Examining the Relationship between Organizational Trust, Organizational Citizenship Behavior and Job Satisfaction (Case study of Customs Department). International Journal of Humanities and Cultural Studies, 2(4), 904-920.

Putra, P. D. P., \& Sriathi, A. A. A. (2017). Pengaruh Perceived Organizational Support dan Komitmen Organisasi Terhadap Organizational Citizenship Behavior. E-Jurnal Manajemen Unud, 6(9), 4800-4828.

Singh, U., \& Srivastava, K. B. L. (2016). Organizational Trust and Organizational Citizenship Behaviour. SAGE Journal, 17(3), 594-609. 
https://doi.org/https://doi.org/10.1177/0972150916630804

Siregar, S., Prasetio, A. P., Telkom, U., Layanan, K., Behavior, O. C., \& Kerja, K. (2015). Pengaruh Kerja dan Komitmen Organisasi Terhadap Organizational Citizenship Behavior (Perilaku OCB) Karyawan Kantor Distribusi PT PLN (Persero) Distribusi Jawa Barat dan Banten. E-Proceeding of Manjement, 2(3), 2707-2714.

Suardani, N. M. D., \& Supartha, I. W. G. (2018). Pengaruh pemberdayaan, kepemimpinan transformasional, dan keadilan organisasional terhadap komitmen organisasional karyawan. E-Jurnal Manajemen Unud, 7(3), 14261451.

Suyono, J., \& Sunaryo, S. (2015). Pengaruh Organizational Citizenship Behavior pada Performance dengan Service Quality, Satisfaction dan Behavior Intention Sebagai Anteseden. Jurnal Ekonomi Bisnis Dan Kewirausahaan, 4(1), 1. https://doi.org/10.26418/jebik.v4i1.11457

Tlaiss, H. A., \& Elamin, A. . (2015). Exploring organizational trust and organizational justice among junior and middle managers in Saudi Arabia. Journal of Management Development, 34(9), 1042 - 1060.

Udayana, K. J. (2015). Pengaruh Komitmen Organisasi Terhadap Prestasi Kerja Karyawan PT. Sekar Nusa Baruna Cabang Singaraja Tahun 2015. Jurnal Undiksha, 5(1), 1-11. 